\title{
Pendampingan Bagi Guru PAUD Dalam Memanfaatkan Microsoft Excel Untuk Pendukung Proses Pembelajaran
}

\author{
Ridha Sefina Samosir ${ }^{1)}$, Erwin Syah Rani ${ }^{2)}$, Lufty Abdillah ${ }^{3)}$ \\ Sistem Informasi, Fakultas Ilmu Komputer dan Desain \\ Jalan Pulomas Selatan, Jakarta Timur 12310 \\ ${ }^{1)}$ Email: ridha.samosir@kalbis.ac.id

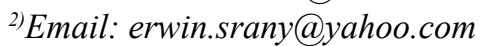 \\ ${ }^{3)}$ Email: lufty.abdillah@kalbis.ac.id
}

\begin{abstract}
The social services for early childhood education teachers ( PAUD) carried ut at Central Cikarang. Based on results discussion during observation and coordination shows that PAUD teachers need computer skills especially for the use of various software that can help their work. At present, demographic data shows that the majority of PAUD teachers are from high school graduates and not good enough in using computer applications. Even though PAUD teachers routinely make reports related to students' learning assessment results, reporting related to learning achievements has been achieved, and other forms of reports. During this time, the teachers rely on an operator or ask other parties to do it. This is very risky because there is a lot of confidential data contained in each of these reports. In addition, there are very few operators in every PAUD school. This is the backgoround of this social services acivity between information system department of Kalbis Institute with HIMPAUDI District Cntre Cikarang. This social services is implemented by assistance methods through workshop activities. This activity is expected to improve the technical expertise of teachers in the field of computers, especially the ability to use icrosoft excel for the learning process.
\end{abstract}

Keywords: Cikarang Pusat, himpaudi, komputer, microsoft excel, pkm

\begin{abstract}
Abstrak: Kegiatan PKM ini dilakukan bagi para guru Pendidikan Anak Usia Dini atau PAUD di Kecamatan Cikarang Pusat. Berdasarkan hasil kordinasi dengan mitra PKM menunjukkan bahwa para guru PAUD membutuhkan keahlian bidang komputer terutama untuk pemamfaatan berbagai perangkat lunak yang dapat membantu pekerjaan mereka. Saat ini, data demografi menunjukkan bahwa sebagian besar guru PAUD disana adalah lulusan SMU dan berada pada level kurang menguasai dalam pemanfaatan aplikasi komputer. Padahal para guru PAUD secara rutin membuat pelaporan terkait hasil penilaian belajar peserta didik, pelaporan terkait capaian pembelajaran telah tercapai, dan bentuk laporan lainnya. Selama ini, para guru mengandalkan seorang operator atau menyuruh pihak lain untuk mengerjakannya. Hal ini sangat beresiko karena ada banyak data-data rahasia yang terkandung dalam setip pelaporan tersebut. Selain itu, keberadaan operator yang ada di setiap sekolah PAUD sangat sedikit. Hal ini yang menjadi latar belakang kegiata PKM yang bersinergi antara himpunan PAUD atau HIMPAUDI di Kecamatan Cikarang Pusat dengan Program Studi Sistem Informasi Kalbis Institute. Kegiatan PKM dilakukan dengan metode pendampingan melalui pelatihan. Kegiatan ini diharapkan dapat meningkatkan keahlian teknik para guru di bidang komputer khususnya keahlian memanfaatkan microsoft excel untuk proses pembelajaran.
\end{abstract}

Kata kunci: Cikarang Pusat, himpaudi, computer, microsoft excel, community services

\section{PENDAHULUAN}

Teknologi komputer semakin berkembang pada revolusi industri 4.0 ini. Salah satu perkembangan teknologi komputer adalah teknologi internet. Data dari lembaga riset pasar e-marketer pada tahun 2013-2018 menunjukkan bahwa saat ini pengguna internet di Indonesia adalah terbesar keenam di dunia. Gambar 1 menunjukkan data pengguna internet di dunia. Perkembangan internet diikuti juga dengan perkembangan perangkat telepon seluler pintar (smartphone). Saat ini kemampuan dari sebuah smartphone semakin meningkat dan secara progressif dapat memenuhi kebutuhan dari penggunanya. Penggunaan smartphone yang terkoneksi internet saat ini dapat dinikmati oleh sebagian besar orang, selain karena harga semakin murah juga karena fitur yang ditawarkan semakin menarik. tidak hanya (www.techno.kompas.com, 2014).

Selain sebagai media penyedia informasi dan alat komunikasi, ada banyak hal yang dapat dilakukan melalui smartphone seperti transaksi belanja, 
transaksi perbankan, dan transaksi lainnya. Bahkan untuk media hiburan seperti musik dengan smule dan spotify, vidio streaming melalui youtube.
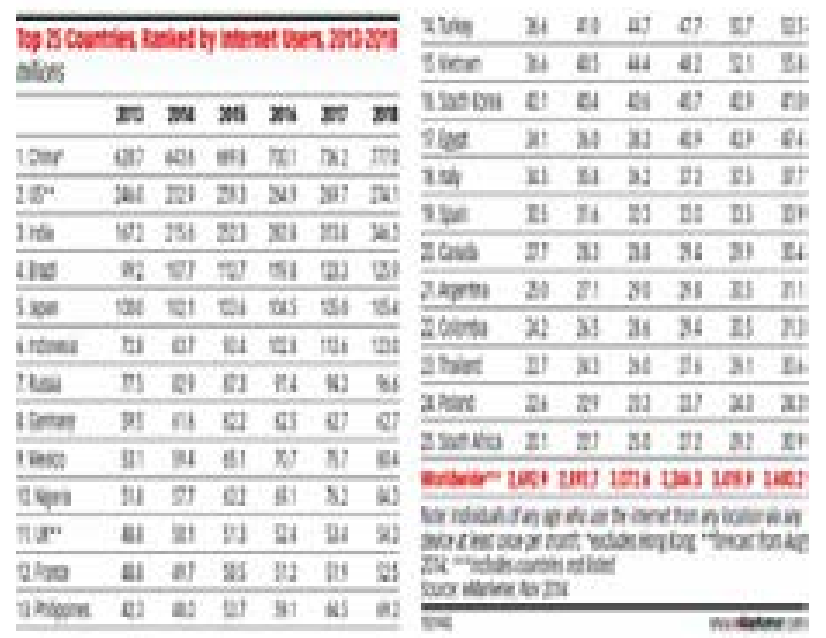

Gambar 1 Data Pengguna Internet

Dunia

Pada Gambar 1. Perkembangan teknologi komputer berpengaruh Pada Berbagai Aspek Kehidupan. Beberapa pekerjaan saat ini membutuhkan pemanfaatan teknlogi komputer seingga pekerjaan tersebut semakin cepat dan mudah untuk diselesaikan. Selain sebagai alat bantu automatisasi, teknologi komputer saat ini juga digunakan sebagai senjata strategis untuk memenangkan persaingan bisnis (Chatrine, S dan Angela, A, 2019)

Program Studi Sistem Informasi merupakan program studi dengan keilmuan yang dominan dalam pemanfaatan teknologi informasi sebagai solusi mupun strategi baik bagi bisnis maupun kepentingan lainnya. Program Studi Sistem Informasi Kalbis Institute berlokasi di daerah Jakarta Timur tepatnya di Pulomas. Program studi ini adalah salah satu dari 9 program studi di Kalbis Institute dengan satu diantaranya adalah program magister (www.kalbis. ac.id, 2020).

Mitra kegiatan PKM adalah Himpunan pendidik dan tenaga kependidikan bagi anak usia dini (HIMPAUDI) di Kecamatan Cikarang Pusat Kabupaten Bekasi Provinsi Jawa Barat. Pendidikan anak usia dini (PAUD) adalah lembaga pendidikan yang bertujuan mengoptimalkan potensi yang dimiliki oleh anak usia dini. PAUD merupakan pendidikan dasar dalam pembelajaran anak. Sehingga PAUD sangat penting bagi pengembangan potensi anak tersebut. Pendidikan yang masuk pada kategori PAUD meliputi Kelompok Bermain, Tempat Penitipan Anak, dan lembaga PAUD lainnya. Adapun kisaran usia anak - anak di lembaga PAUD adalah 2-5 tahun (Nopika, D.A, dkk, 2019). Sebaiknya anak-anak di lembaga PAUD hanya dibekali dengan permainan edukasi, cara bersosialisasi, dan softkills lainnya. Lembaga PAUD tidak disarankan untuk mengajarkan anak-anak dengan teknik baca, tulis, dan hitung (CALISTUNG) (Megawangi, R, 2004).

Sedangkan HIMPAUDI atau himpunan pendidik dan tenaga kependidikan bagi anak usia dini adalah sebuah organisasi yang mengumpulkan guru dan tenaga pendidik bagi lembaga-lembaga pendidikan anak usia dini yang bertingkat dari level kecamatan, kabupaten sampai level provinsi. Organisasi sosial sebagai wadah bagi para guru dan tenaga pendidik di lembaga PAUD untuk bersosialisasi, saling tolong menolong, dan fungsi lainnya. HIMPAUDI dari level kecamatan harus melaporkan kegiatannya kepada pengurus HIMPAUDI tingkat kabupaten, demikian juga dari kabupaten ke tingkat provinsi.

HIMPAUDI Kecamatan Cikarang Pusat berada di Desa Sukamahi Kecamatan Cikarang Pusat Kabupaten Bekasi. Kantor sekretariat dari HIMPAUDI Kecamatan Cikarang Pusat berlokasi di TK Al Munawaroh yang berlokasi di Jln. Raya sukamahi RT. 004/002 Desa Sukamahi Kecamatan Cikarang Pusat, Kabupaten Bekasi.

Adapun Himpunan PAUD (HIMPAUDI) Kecamatan Cikarang Pusat Kabupaten Bekasi memiliki enam kelurahan antara lain kelurahan Cicau, Sukamahi, Pasir Ranji, Pasir Tanjung, Hegarmukti dan Jayamukti. Kelurahan Cicau memiliki dua buah kelompok bermain (KB), kelurahan Sukamahi memiliki tuga buah kelompok bermain (KB), kelurahan Pasir Ranji memiliki dua buah kelompok bermain (KB), kelurahan Pasir Tanjung memiliki empat buah kelompok bermain (KB), kelurahan Hegarmukti memiliki tiga buah kelompok bermain (KB), dan kelurahan Jayamukti memiliki empat buah kelompok bermain (KB).

Status sosial dari HIMPAUDI Kecamatan Cikarang Pusat Kabupaten Bekasi sebagai mitra pengabdian kepada masyarakat saat ini berada pada taraf menengah. Hal ini dapat dilihat dari latar belakang anggota dan pengurus yang turut bergabung kedalam organisasi ini. Taraf menengah ditunjukkan dari kendaraan maupun media komunikasi yang digunakan. Tetapi dari latar belakang pendidikan, menujukkan bahwa kebanyakan guru PAUD merupakan lulusan SMU yang mengabdikan dirinya untuk mengajar anak-anak usia dini. Walaupun ada beberapa dari mereka yang sedang studi lanjut untuk tingkat diploma atau sarjana

Berdasarkan hasil observasi dan diskusi antara mitra PKM dan Program Studi Sistem Informasi 
Kalbis Institute merumuskan beberapa masalah yang terindentifikasi oleh tim Program Studi Sistem Informasi, yaitu:

1. Kategori keahlian guru dan tenaga kependidikan di PAUD Kecamatan Cikarang Pusat masih membutuhkan pendampingan dalam pemanfaatan aplikasi komputer melalui berbagai pelatihan. Sebagian besar guru dan tenaga kependidikan masih sangat awam dengan berbagai teknologi-teknologi pendukung proses pembelajaran di PAUD. Bahkan banyak para guru yang belum mengenal sama sekali berbagai teknologi tersebut. Sebagai contoh adalah bahwa para guru tersebut masih sangat canggung bahkan ada yang belum bisa menyalahkan laptop masing-masing. Atau para guru maupun tenaga pendidik belum mengetahui namanama setiap peranngkat yang ada tersebut.

2. Permasalahan lainnya adalah bahwa saat ini jumlah tenaga ahli bidang komputer dan teknologi informasi atau operator yang diandalkan sangat sedikit untuk setiap PAUD di lingkungan Kecamatan Cikarang Pusat. Bahkan ada sekolah PAUD yang tidak memiliki operator. Pada beberapa kasus menunjukkan bahwa terkadang beberapa sekolah PAUD lebih memilih membayar jasa operator untuk membantu para guru maupun tenaga kependidikan tersebut dalam menyelesaikan laporan pembelajaran yang membutuhkan microsoft excel dalam pembuatannya. Solusi yang melibatkan pihak ketiga yang berbayar akan sangat beresiko karena kebanyakan data yang mereka gunakan untuk pembuatan laporan merupakan data-data rahasia. Adapun bentuk resiko yng mungkin terjadi adalah bahwa data tersebut disebarluaskan maupun resiko laporan dapat diduplikasi.

3. Para guru maupun tenaga kependidikan di lingkungan PAUD harus melaporkan kegiatan pembelajaran secara rutin setiap semester kepada pengurus HIMPAUDI tingkat kabupaten yaitu Kabupaten Bekasi. Pembuatan laporan rutin oleh guru dan tenaga pendidik di PAUD membutuhkan perangkat microsoft office seperti microsoft word, dan microsoft excel. Pelaporan secara rutin ini sebaiknya diikuti dengan peningkatan wawasan serta keahlian teknis para guru dan tenaga kependidikan agar dapat mengerjakan laporan secara mandiri oleh setiap PAUD.

4. Selain kebutuhan akan pembuatan laporan rutin setiap semester, para guru maupun tenaga pendidik perlu mempersiapkan materi pembelajaran kepada peserta didik. Dan beberapa materi pembelajaran tersebutjuga membutuhkan keterlibatan dari perangkat lunak seperti microsoft excel.
Berbagai permasalahan di atas lah yang menjadi latarbelakang dari dilaksanakan nya kegiatan kemitraan antara HIMPAUDI Kecamatan Cikarang Pusat dengan tim dari Program Studi Sistem Informasi Kalbis Institute. Secara khusus, bagi tim program studi, kegiatan PKM ini merupakan bentuk kewajiban dosen dari Tri Dharma Perguruan Tinggi yaitu Pengabdian Kepada Masyarakat. Menurut peraturan pemerintah di PERMENRISTEKDIKTI bahwa kegiatan pengabdian kepada masyarakat merupakan salah satu bentuk pembelajaran di perguruan tinggi. Dan bentuk pembelajaran ini merupakan standar nasional yang berlaku di perguruan tinggi. Sebagai bentuk pembelajaran maka seluruh dosen dan mahasiswa berkewajiban melaksanakan nya. Salah satu bentuk pengabdian kepada masyarakat adalah melalui pelatihan terkait keilmuan yang dimiliki oleh program studi untuk meningkatkan kesejateraan masyarakat di sekitarnya (PERMENRISTEKDIKTI, 2015).

Dari penjelasan di atas maka HIMPAUDI Kecamatan Cikarang Pusat membutuhkan pelatihan dalam memanfaatkan teknologi komputer yang menunjang proses pembelajaran pada setiap semester termasuk kebutuhan pembuatan laporan pembelajaran. Salah satu teknologi yang menjadi fokus adalah microsoft excel karena laporan kegiatan pembelajaran setiap semester oleh guru maupun tenaga kependidikan di lingkungan PAUD membutuhkan peran dari aplikasi microsoft excel.

Microsoft excel merupakan salah satu perangkat lunak atau aplikasi yang ada dalam grup microsoft office. Aplikasi microsoft excel adalah aplikasi yang fungsinya untuk pengolahan data berupa angka. Ada banyak fitur atau fasilitas di microsoft excel yang dapat digunakan untuk kepentingan banyak hal. Bahkan pengolahan data dengan teknik statistika sederhana dan kompleks berupa mean, modus, varian, standar deviasi, dan lainnya dapat dilakukan (Kasiyanto, K, 2016). Selain pengolahan data dengan teknik statistika, ada fungsi-fungsi di microsoft excel yang dapat digunakan untuk pengeolahan data bisnis seperti data pelanggan, data penjualan, data vendor, data bahan baku, dan data lainnya. Microsoft excel juga memilki fitur untuk membuat aplikasi sederhana dengan bahawa pemrograman VB. Sehingga sebuah aplikasi sederhana kita dapat bangun hanya dengan menggunakan microsoft excel. Ada banyak versi microsoft excel yang mengikuti versi dari microsoft office nya (Ibnu, T.W, 2017). Oleh karena itu tujuan dari kegiatan PKM ini adalah melaksanakan 
pendampingan melalui berbagai pelatihan-pelatihan dalam pemanfaatan microsoft excel bagi guru dan tenaga kependidkan di lingkungan HIMPAUDI Kecamatan Cikarang Pusat.

\section{METODE PELAKSANAAN}

Adapun metode dalam pelaksanaan PKM ini adalah dengan metode pendampingan melalui kegiatan pelatihan teknis pemanfaatan microsoft excel secara bertahap. Pendampingan berarti adanya keterlibatan dari pendamping pada kegiatan pelatihan. Pendamping tersebut bertujuan mengarahkan, memberikan petunjuk, dan memberikan bimbingan kepada peserta pelatihan agar peserta pelatihan memahami materi pelatihan yang disampaikan (Galih, DSR dan Dida, F, 2018).

Pendampingan dilakukan dari mulai proses observasi dalam rangka identifikasi beberapa permasalahan - permasalahan yang ada (Yeni, P.S, dkk, 2019). Sampai dengan evaluasi kegiatan PKM. Setiap tahap didampingi oleh tim dari program studi baik pendampingan oleh dosen maupun oleh mahasiswa.

Kegiatan pendampingan saat observasi adalah dengan mengarahkan mitra dalam penggalian kebutuhan pelatihan dari mitra. Dan pendampingan saat pelaksanaan pelatihan akan dibantu oleh mahasiswa yang berperan sebagai fasilitator. Jadi, ketika dosen meyajikan materi pelatihan dengan media presentasi maka mahasiswa berhadapan langsung dengan peserta pelatihan. Sedangkan pendampingan saat evaluasi adalah dalam bentuk pengarahan juga untuk mencari tahu hal-hal apa saja yang masih perlu diperbaiki dan harus dilakukan oleh tim PKM dan mitra.

Sebagai program studi yang terkait dengan bidang teknologi dan bisnis maka Program Studi Sistem Informasi Kalbis Institute mengusulkan pelatihan yang sesuai keilmuan program studi dan dapat membantu mengatasi permasalahan disana serta mengacu pada Visi dan Misi HIMPAUDI yaitu mewujudkan organisasi profesi yang profesional, mandiri dan mengayomi. Adapun materi pelatihan yang diberikan adalah microsoft excel tingkat dasar untuk membantu pengolahan nilai, pengolahan data kehadiran siswa, pengolahan data keuangan, dan pengolahan data lainnya.

\section{A. Pelaksanaan PKM}

Pelaksanaan PKM dibagi menjadi 3 tahap yaitu persiapan, pelaksanaan, dan evaluasi. Tahap persiapan dimulai dari observasi serta kordinasi tim PKM ke lokasi mitra sampai diperoleh kesepakatan anatara kedua pihak. Saat observasi dan kordinasi antara kedua pihak maka disepakati beberapa hal seperti topik maupun fokus pelatihan yang sesuai dengan permasalahan, lokasi pelatihan, waktu pelatihan, dan peserta pelatihan.

Hasil kesepakatan, tempat pelatihan adalah di TK Al Munawaroh Desa Sukamahi. Kecamatan Cikarang Pusat Kabupaten Bekasi. Adapun jarak antara kampus Kalbis Institute dengan lokasi PKM adalah sekitar $48 \mathrm{~km}$. Gambar 2 merupakan peta lokasi yang menunjukkan jarak antara mitra dengan kampus Kalbis Institute.

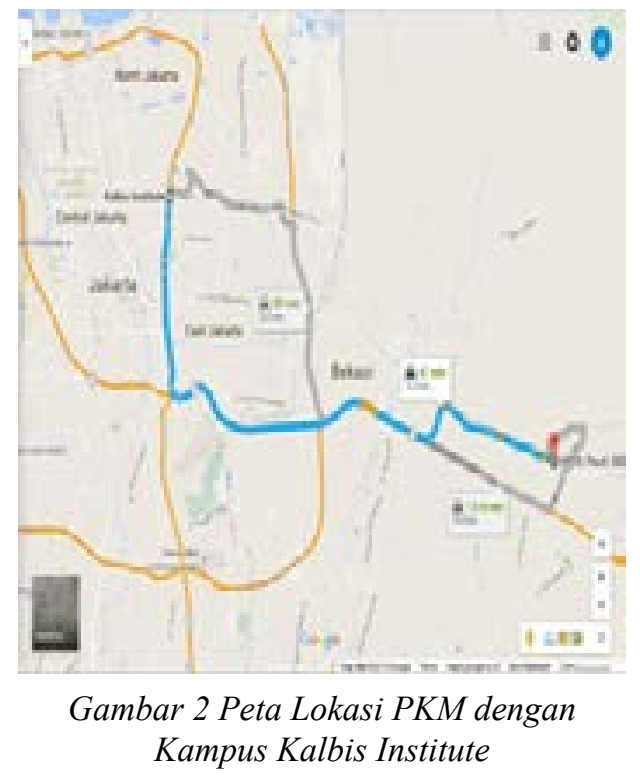

Kesepakatan lainnya adalah waktu pelaksanaan yaitu pelatihan dilakukan pada bulan november tahun 2019. Adapun peserta pelatihan adalah perwakilan beberapa guru dan tenaga kependidikan dari setiap PAUD di Kecamatan Cikarang Pusat yang terdaftar di HIMPAUDI Kabupaten Bekasi

Pada tahap persiapan, pihak mitra mempersiapkan data peserta pelatihan melalui proses pendataan dari setiap PAUD yang ada di lingkungan kecamatan Cikarang Pusat. Pihak mitra berkordinasi dengan pengurus dari masing-masing PAUD dalam pendataan peserta. Dari seluruh peserta yang terdata selanjutnya akan dibagi menjadi beberapa kelas kecil sehingga setiap kelas hanya berkisar 10-15 peserta pelatihan. Hal ini bertujuan agar peserta dapat dengan mudah memahami dan mengerjakan latihan yang diberikan oleh instruktur.

Selain tempat juga mempersiapkan media untuk penyampaian materi kepada peserta PKM seperti infocus, dan media lainnya seperti pointer sebagai alat penggerak dan penunjuk materi presentasi. 
Pemateri juga membutuhkan alat tulis seperti spidol maupun penghapus karena tim PKM akan sesekali menjelaskan detail materi dengan media tersebut.

Bagi tim dari Program Studi Sistem Informasi juga dipersiapkan modul pelatihan. Modul ini disusun oleh seluruh tim yang terlibat melalui kegiatan rapat seluruh tim. Modul yang disusun menyesuaikan dengan kesepakatan topik hasil observasi dan kordinasi dengan mitra PKM. Modul pelatihan terdiri dari materi pengenalan microsoft excel sampai dengan materi penggunaan fungsi-fungsi yang ada pada microsoft excel baik fungsi matematika, fungsi statistik, dan fungsi bisnis. Materi yang disajikan pada modul yang diberikan adalah materi tingkat dasar dari microsoft excel.

Selain modul pelatihan, tim PKM dari Program Studi Sistem Informasi juga mempersiapkan beberapa mahasiswa yang berperan sebagai fasilitator saat pelatihan. Mahasiswa ini akan membantu tim dosen ketika ada pertanyaan atau kesulitan yang dialami oleh peserta pelatihan. Sesuai dengan metode pelaksanaan PKM adalah pendampingan. Jumlah fasilitator yang dilibatkan adalah sebanyak dua orang mahasiswa per kelas pelatihan.

\section{HASIL DAN PEMBAHASAN}

Kegiatan pelatihan dilakukan pada tanggal 08 November 2019 dari mulai pukul 08.00-17.00 WIB. Pelatihan dilakukan di TK AL Munawaroh Desa Sukamahi. Pelatihan dimulai pukul 08.00 WIB yang dimulai dengan registrasi ulang peserta pelatihan serta pendataan instruktur setiap kelas. Registrasi ulang dilakukan sekitar 30 menit. Lalu dilanjutkan dengan pembukaan oleh pembawa acara dan penilik PAUD yaitu bapak Drs. Aminuddin. Sebagai lembaga pendidikan, PAUD juga berada di bawah pengawasan negara dalam pelaksanaannya tepatnya kementerian pendidikan nasional. Sehingga setiap kabupaten terdapat beberapa aparatur sipil negara yang ditugaskan sebagai penilik di lembaga-lembaga PAUD. Penilik-penilik ini bertugas mengawasi proses pembelajaran di lembaga-lembaga PAUD.

Selang 30 menit kemudian dari acara pembukaan maka modul 1 dimulai. Modul 1 berupa pengenalan microsoft excel. Modul 1 ini dipaparkan oleh dosen tetap dengan tim mahasiswa sebagai fasilitator. Pada modul 1 ini, peserta diperkenalkan dengan berbagai toolbar, menu bar, title bar, quick access, office button, dan tombol lainnya. Selain mengenal simbol atau icon masing-masing menu tersebut juga diperkenalkan fungsi dari menu-menu tersebut. Pada modul 1 juga berisi cara memulai dokumen excel, membuka dan menutup file, dan menyimpan file. Modul 1 disajikan dengan menggunakan media berupa gambar yang mewakili icon dari berbagai menu pada microsoft excel. Tidak semua menu disampaikan, hanya menu-menu yang memang dibutuhkan secara rutin oleh guru dan tenaga pendidik di PAUD dalam proses pembelajaran. Setelah materi modul 1 diakhiri dengan evaluasi melalui latihan soal. Latihan soal pada modul 1 adalah menjelaskan kembali fungsifungsi dari masing-masing icon pada microsoft excel.

Modul kedua dilanjutkan dengan mulai bekerja dengan microsoft excel. Peserta diberi materi dari paling sederhana atau tingkat dasar. Materi modul kedua yang diberikan meliputi worksheet, range, sel, outfill, teks, pengurutan, penggabungan sel, copy sel, dan lain-lain. Pada intinya, modul kedua berisi cara menggunakan microsoft excel untuk membuat sel, mengisi sel, mengubah jenis huruf di setiap sel, mengurutkan secara otomatis berupa nomor urut, nama hari, nama bulan, dan urutan lainnya. Sebagai contoh, pada modul kedua ini, peserta mengetahu bahwa tidak perlu memasukkan satu persatu data yang sifatnya urutan seperti nomor, nama hari, nama bulan, dan lainnya. Peserta didik dibekali bahwa hanya dengan mengisi dua sel secara berurut maka dengan microsoft excel, sel berikutnya akan terisi urutannya secara otomatis. Gambar 3 adalah contoh pengurutan dalam microsoft excel.

Setelah modul kedua, peserta diberikan latihan soal untuk dipraktekkan. Tujuan latihan soal ini adalah memonitor ketercapaian capaian pembelajaran dari modul 2.

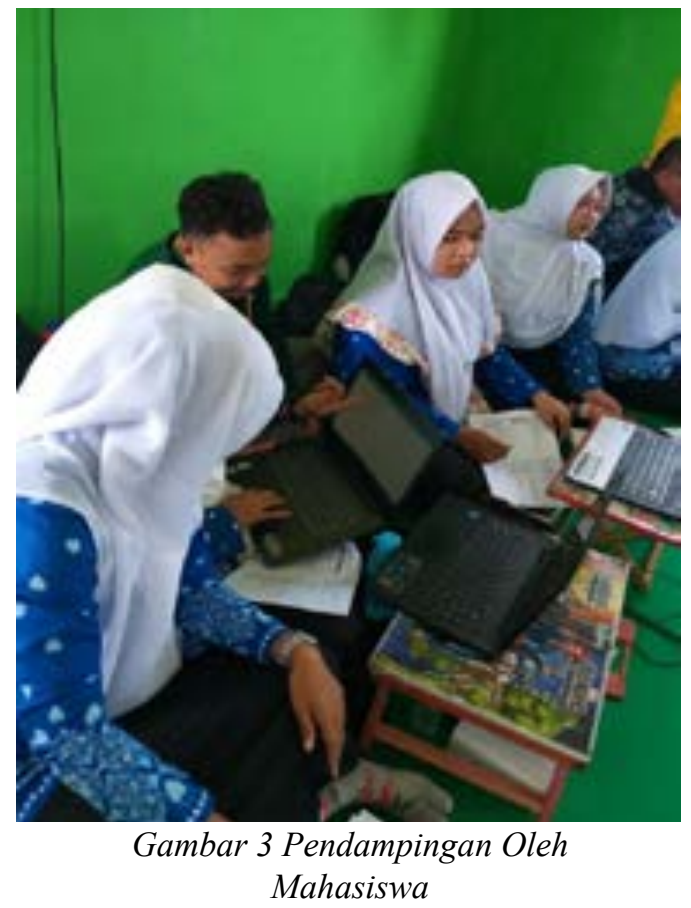


Kemudian materi dilanjutkan dengan pembuatan tabel dengan microsoft excel. Pada materi pelatihan modul ketiga ini dimulai dari pembuatan tabel sederhana, border tabel, insert, delete, copy, dan fungsi lainnya yang dapat memanipulasi tabel. Materi manipulasi tabel meliputi penyisipan isi tabel di awal, di tengah, atau di akhir baris dari tabel. Selain penyisipan, juga bagaimana menghapus isi dari tabel baik yang berada di awal, di tengah maupun di akhir baris dari tabel. Peserta juga dapat membuat header dari tabel sesuai dengan kebutuhan atau agar tabel lebih mudah difahami.

Misalkan membuat jenis huruf (font) dari setiap header, membuat tulisan header miring dengan berbagai arah, memmberi warna berbeda antara heder dengan baris data, dan bentuk manipulasi header tabel lainnya. Materi modul ketiga ini diakhiri dengan pemberian latihan soal yaitu membuat tabel penilaian peserta didik. Tabel terdiri dari beberapa baris dan kolom. Materi modul ketiga ini cukup lama karena diberikan secara bertahap. Dengan pertimbangan dari data kemampuan peserta pelatihan maka materi modul ketiga disampaikan dengan cara yang sederhana dan mudah dipraktekkan. Selain itu, diberikan berulangulang sampai peserta pelatihan memahami dan bisa mengeksekusi langsung dengan microsoft excel.

Materi terahir adalah modul keempat yaitu menyampaikan materi tentang fungsi-fungsi pada Microsoft excel. Fungsi-fungsi tersebut meliputi fungsi matematika, fungsi statistika, fungsi untuk bisnis, dan fungsi lainnya. Pada masing-masing kategori hanya diberikan maksimal 5 fungsi sehingga peserta tidak terlalu bingung karena materi mengenai fungsi dibuat sesederhana mungkin. Kelima fungsi dari masing-masing kriteria disesuaikan dengan format kebutuhan laporan rutin oleh guru dan tenaga pendidik di PAUD setiap semester. Modul keempat juga diberikan latihan soal yang merupakan lanjutan dari modul ketiga. Jadi pada latihan soal ini, peserta pelatihan diminta membuat tabel penilaian. Dan pada tabel tersebut diberikan fungsi-fungsi untuk menjumlahkan total nilai, fungsi mencari rata-rata nilai, fungsi mencari nilai tertinggi, fungsi mencari nilai terendah, dan fungsi lainnya.

Seluruh modul diberikan dengan cara bertahap sehingga peserta didik dapat memahami materi yang diberikan. Materi pelatihan dan latihan soal selesai diberikan pada pukul 17.00 WIB. Lalu dilanjutkan dengan foto bersama peserta dan instruktur. Diakhiri dengan penutup dari instruktur dan dari perwakilan HIMPAUDI Kecamatan Cikarang Pusat. Seperti pada Gambar 4.

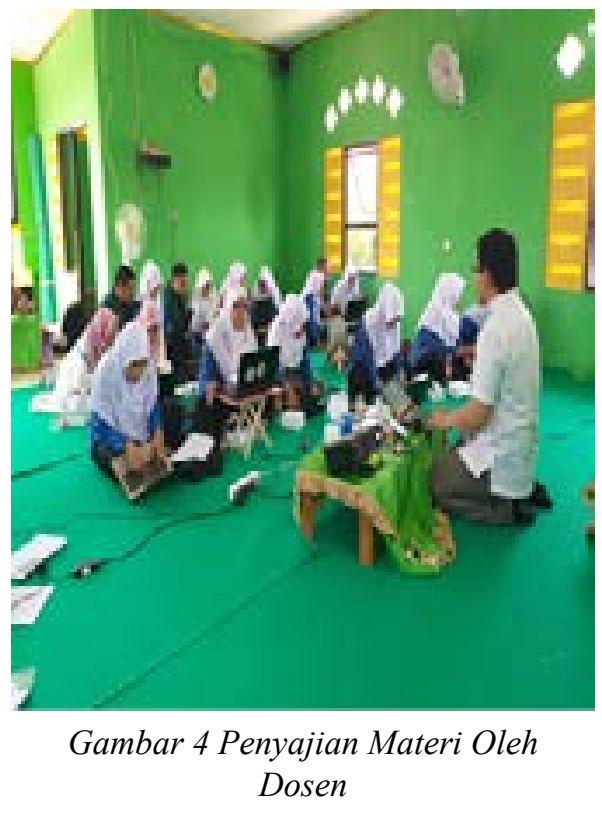

Dari kegiatan yang telah dilakukan menunjukkan bahwa antusias dari peserta cukup baik melalui pengajuan beberapa pertanyaan dari peserta. Saat kegiatan pelatihan juga teridentifikasi bahwa sebagian besar peserta belum mahir menggunakan microsoft excel. Terlihat bahwa hanya 1-2 peserta yang sudah cukup mengenal dan familiar dengan beberapa fungsi dari microsoft excel.

Indikator keberhasilan kegiatan pelatihan juga diperoleh dari hasil pengukuran indeks kepuasan mitra berdasarkan isian kusioner oleh peserta pelatihan (I Gede, KPTB dan Ni Kadek,S, 2017). Pada kuisioner diberikan 10 pernyataan yang meminta peserta memberikan tanggapan terhadap pernyataan pada kuisioner tersebut. Hasil analisis indeks kepuasan yang disajikan pada artikel ilmiah ini mewakili beberapa kelas pelatihan yang dilaksanakan. Ada 14 kusioner yang diisi oleh peserta pelatihan dari salah satu kelas tersebut. Isian kuisioner kemudian diolah menggunakan microsoft excel oleh tim PKM dari Program Studi Sistem Informasi. Adapun teknik analisis yang digunakan adalah teknik regresi multi variabel. Keluaran dari analisis indeks kepuasan peserta adalah indeks kepuasan yang dikonversi dalam tiga kategori yaitu cukup, baik, dan kurang baik. Indeks kepuasan peserta pada kategori kurang berkisar dari 1.00 - 2.99, kategori cukup berkisar 3.00-4.99, dan kategori baik berkisar pada 5.00-7.00.

Setelah melalui pengolahan data, hasil analisis indeks kepuasan peserta terhadap pelatihan yang dilaksanakan oleh tim PKM adalah berada pada kategori baik karena indeks kepuasan peserta yang diperoleh adalah 5.81. Dari indeks kepuasan peserta maka dapat dilihat bahwa peserta pelatihan menyukai cara pemaparan materi oleh tim PKM, materi yang 
disajikan juga sederhana dan mudah difahami, tim fasilitator sangat membantu peserta untuk memahami materi teknis, serta indikator lainnya yang tertera pada kuisioner. Gambar 5 adalah hasil analisis indeks kepuasan peserta terhadap pelatihan yang diberikan.

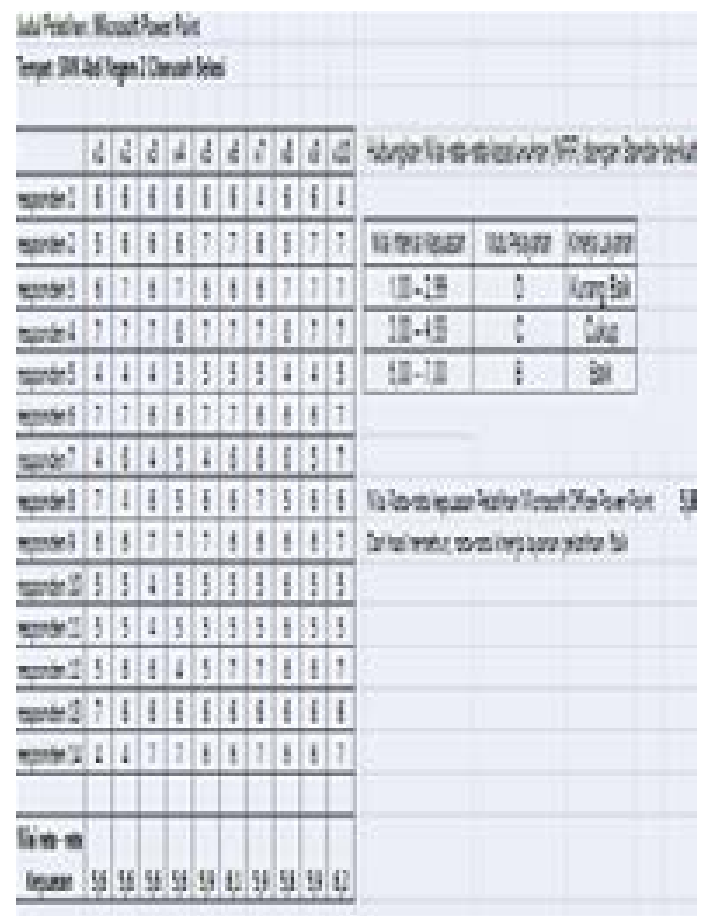

Gambar 5 Indeks Kepuasan Peserta

\section{SIMPULAN}

Adapun kesimpulan dari seluruh rangkaian kegiatan yang telah dilakukan adalah sebagai berikut:

1. Guru-Guru PAUD Kecamatan Cikarang Pusat membutuhkan pelatihan dalam rangka meningkatkan wawasan dan keahlian mereka dalam memanfaatkan microsoft excel.

2. Peserta pelatihan dapat mengikuti pelatihan dengan baik. Hal ini terlihat dari hasil evaluasi sebelum dan sesudah pelatihan. Dan juga dapat dilihat dari hasil analisis indeks kepuasan peserta.

3. Peserta membutuhkan materi yang disampaikan dengan cara sederhana dan tidak terlalu banyak. Juga disajikan secara perlahan-lahan dengan bahasa atau istilah yang paling mudah untuk difahami.

4. Peserta pelatihan membutuhkan pelatihan teknis terkait pemanfaatan perangkat lunak yang dapat mendukung proses pembelajaran termasuk kebutuhanpembuatan laporan proses pembelajaran secara rutin setiap semester

5. Peserta membutuhkan kegiatan pelatihan rutin dilakukan dengan materi tidak terlalu banyak. Selain itu penyampaian materi juga disampaikan dengan cara yang sederhana.

6. Fasilitator atau pendamping dari mahasiswa sangat membantu peserta pelatihan secara teknis. Peserta dapat langsung menanyakan kepada fasilitator mahasiswa jika ada hal yang tidak mereka fahami atau tidak dapat mereka praktekkan secara langsung, atau juga karena ada kendala lainnya.

7. Versi microsoft excel yang terinstall pada masing-masing laptop peserta berbeda-beda. Bahkan terdapat versi yang sangat jauh antara peserta. Padahal perbedaaan versi dari microsoft excel mempengaruhi fitur-fitur yang dapat digunakan. Selain itu, perbedaan versi juga mempengaruhi simbol-simbol yang digunakan. Jadi ketika dosen menjelaskan materi dengan simbol microsoft excel versi baru atau 2010 ke atas sering sekali peserta kewalahan mencari simbol yang sama pada versi microsoft excel yang mereka gunakan. Sering sekali ada simbol yang tidak ada pada versi lama tetapi muncul pada versi baru. Variasi versi microsoft excel yang digunakan peserta pelatihan cukup tinggi sehingga para pendamping atau fasilitator perlu menjelaskan satu persatu ke setiap peserta.

8. Ada beberapa peserta pelatihan yang telah sangat lama tidak mengopeasikan laptop yang ia gunakan dan laptop tersebut dalam posisi terkunci dan membutuhkan password untuk membukanya. Oleh karena lama sekali tidak digunakan maka peserta pelatihan lupa password yang digunakan. Sehingga dosen maupun pendamping mahasiswa perlu meluangkan waktu lagi untuk me reboot sistem operasi windows yang digunakan sehingga dapat menghilangkan fungsi pemasangan password ketika login ke sistem operasi windows nya.

Berdasarkan seluruh rangkaian kegiatan PKM yang dilakukan dari mulai persiapan sampai dengan tahap evaluasi, tim PKM merekomendasikan beberapa hal sebagai berikut: (1). Saat pelaksanaan pelatihan, sebaiknya melibatkan lebih banyak bantuan mahasiswa sebagai fasilitator atau pendamping bagi para peserta. Hal ini terkait kemampuan teknis peserta pelatihan dari yang paling sederhana menunjukkan bahwa peserta membutuhkan pendampingan secara langsung; (2). Materi yang disajikan jangan terlalu banyak dan detail. Penjelasan detail sebaiknya langsung oleh pedamping (fasilitator); dan (3). Saat kordinasi dan observasi sebaiknya dilakukan lebih lama agar dapat mengidentifikasi permasalahan yang terjadi dengan tepat.

\section{DAFTAR RUJUKAN}

http://tekno.kompas.com/read/2014/11/24/07430087/ Pengguna.Internet.Indonesia.Nomor.Enam.Dunia. 
Diakses 21 Januari 2020 [ONLINE].

Chatrine, S dan Angela, A. 2019. Perencanaan Strategis Sistem dan Teknologi Informasi Pada STMIK-STIE Mikroskil Menggunakan Metode WARD \& PREPARD. Vol. 23. No.2. SEBATIK. STMIK Widya Cipta Dharma. Hal.592-603.

http://kalbis.ac.id/akademik/sistem-Informasi-s1. Diakses 31 Januari 2020 [ONLINE]

Nopika, D.A, Siti, R.A, dan Agus, S. 2019.Optimalisasi Pendidikan Anak Usia Dini Berdasarkan Pembelajaran Yang Berbasis Perkembangan Otak. Vol. 2. No.2. Jurnal CERIA. Hal. 29-36.

Megawangi, R. et al.. 2004. Pendidikan yang Patut dan Menyenangkan: Penerapan Teori Developmentally Appropriate Pracices (DAP) Anak-anak Usia Dini 0 sampai 8 tahun. Cimanggis: Indonesia Heritage Foundation.

Peraturan Menteri Riset dan Teknologi Pendidikan Tinggi No 44 Tahun 2015 tentang Standar Nasional Pendidikan Tinggi.
Kasiyanto. K. 2016. Agresi Perkembanngan Teknologi Informasi. Edisi Satu. Jakarta: PRENADAMEDIA GROUP.

Ibnu, T.W. 2017. Belajar Formula dan Fungsi Microsoft excel. Edisi Satu. Jakarta: Anak Hebat Indonesia

Galih, D.S.R dan Dida, F. 2018. Pengembangan Pembelajaran Innovative Berbasis Pendampingan Bagi Guru Sekolah Dasar. Vol.1. No.1. Jurnal Pengabdian Kepada Masyarakat (ABDIMAS). IKIP Siliwangi Hal. 17-25.

Yeni, P.S, Ida, F, dan Hetika. 2019. Model Pendampingan Umkm Pengolahan Hasil Laut Dengan Metode Pendekatan Pendampingan Terintegrasi. Vol.8. No.1. Jurnal MONEX. Hal. 293-302.

I Gede, KTPB dan Ni Kadek, S. 2017. Pengukuran Customer Satisfaction Index Terhadap Pelayanan di Century Gym. Vol.7. No.1. Jurnal ILMIAH SISFOTENIKA. STMIK Pontianak. Hal. 25-37. 